\title{
Dopamine transporter in attention-deficit hyperactivity disorder normalizes after cessation of methylphenidate
}

Citation for published version (APA):

Feron, F. J. M., Hendriksen, J. G., van Kroonenburg, M. J. P. G., Blom-Coenjaerts, C., Kessels, A. G. H., Jolles, J., Weber, W. E. J., \& Vles, J. S. H. (2005). Dopamine transporter in attention-deficit hyperactivity disorder normalizes after cessation of methylphenidate. Pediatric Neurology, 33(3), 179-83.

https://doi.org/10.1016/j.pediatrneurol.2005.04.008

Document status and date:

Published: 01/01/2005

DOI:

10.1016/j.pediatrneurol.2005.04.008

Document Version:

Publisher's PDF, also known as Version of record

Please check the document version of this publication:

- A submitted manuscript is the version of the article upon submission and before peer-review. There can be important differences between the submitted version and the official published version of record.

People interested in the research are advised to contact the author for the final version of the publication, or visit the DOI to the publisher's website.

- The final author version and the galley proof are versions of the publication after peer review.

- The final published version features the final layout of the paper including the volume, issue and page numbers.

Link to publication

\footnotetext{
General rights rights.

- You may freely distribute the URL identifying the publication in the public portal. please follow below link for the End User Agreement:

www.umlib.nl/taverne-license

Take down policy

If you believe that this document breaches copyright please contact us at:

repository@maastrichtuniversity.nl

providing details and we will investigate your claim.
}

Copyright and moral rights for the publications made accessible in the public portal are retained by the authors and/or other copyright owners and it is a condition of accessing publications that users recognise and abide by the legal requirements associated with these

- Users may download and print one copy of any publication from the public portal for the purpose of private study or research.

- You may not further distribute the material or use it for any profit-making activity or commercial gain

If the publication is distributed under the terms of Article $25 \mathrm{fa}$ of the Dutch Copyright Act, indicated by the "Taverne" license above, 


\title{
Dopamine Transporter in Attention-Deficit Hyperactivity Disorder Normalizes After Cessation of Methylphenidate
}

\author{
Frans J. M. Feron, MD*, Jos G. M. Hendriksen, PhD, ${ }^{\dagger \neq}$ \\ Marinus J. P. G. van Kroonenburgh, $\mathbf{M D}$, PhD $^{\S}$, Ciska Blom-Coenjaerts, $\$$ \\ Alfons G. H. Kessels, MD", Jelle Jolles, PhD ${ }^{\ddagger}$, Wim E. J. Weber, MD, PhD, ${ }^{\mathbb{I}}$ \\ and Johan S. H. Vles, MD, PhD ${ }^{\dagger \top}$
}

\begin{abstract}
Attention-deficit hyperactivity disorder (ADHD) is a common neurodevelopmental disorder of childhood, which is frequently treated with methylphenidate. The short-term response to treatment with methylphenidate is a substantial decrease in dopamine transporter density, with improvement in neuropsychological tests. In this study, single-photon emission computed tomography was used to investigate possible long-term alterations in the cerebral dopamine system after cessation of treatment with methylphenidate in five children with ADHD. Three months after initiation of treatment with methylphenidate, a reduction of the dopamine transporter in the striatal system was observed. Methylphenidate was administered for a period of 9 to 20 months. Follow-up with single-photon emission computed tomography after withdrawal of methylphenidate medication disclosed an increase of dopamine transporter activity comparable with pretreatment values. The observed upregulation of dopamine transporter activity might support the assumption that methylphenidate does not lead to permanent damage of the nigrostriatal dopaminergic pathways. (C) 2005 by Elsevier Inc. All rights reserved.
\end{abstract}

Feron FJM, Hendriksen JGM, van Kroonenburgh MJPG, Blom-Coenjaerts C, Kessels AGH, Jolles J, Weber WEJ, Vles JSH. Dopamine transporter in attention deficit hyperactivity disorder normalizes after cessation of methylphenidate. Pediatr Neurol 2005;33:179-183.
Introduction

Attention-deficit hyperactivity disorder (ADHD), a common neurodevelopmental disorder of childhood, is a clinically heterogeneous syndrome, with core symptoms of inattention, excessive motor activity, and impulsivity. The therapeutic use of methylphenidate for the management of children with ADHD is increasing on a large scale, as its short-term efficacy in modifying motor, cognitive, and affective responses is well documented [1-4]. Trials with 14 to 24 months of follow-up suggested that consistent use of stimulant medication was associated with maintenance of effectiveness [5,6].

However, as ADHD can persist into adulthood, concern has been raised about the possible negative effects of long-term exposure of developing brains to methylphenidate $[3,4,7]$. Data on chronic methylphenidate use and abuse are scarce. In addition, the possibility that methylphenidate, like other psychostimulant amphetamine derivatives, might produce toxic effects on central monoaminecontaining neurons has received relatively little attention [8]. Extrapolating experimental animal data, methylphenidate is probably safer than amphetamine, because it lacks the dopamine neurotoxic potential that has been well documented for amphetamine [8]. However, data in children related to this topic are unavailable.

Recent research suggests that the cerebral dopamine transporter is the primary target for methylphenidate in ADHD patients [4]. Both adults and children with ADHD appear to have increased dopamine transporter binding

From *Youth Health Care Division of the Regional Public Health Institute Maastricht, Maastricht, The Netherlands, ${ }^{\ddagger}$ Departments of Child Neurology, " Neurology, ${ }^{\mathbb{8}}$ Nuclear Medicine, ${ }^{\ddagger}$ Psychiatry and Neuropsychology, and "Clinical Epidemiology and Medical

Technology Assessment, University Hospital Maastricht, Maastricht, The Netherlands.

Communications should be addressed to:

Dr. Feron; Youth Health Care Division of the Regional Public Health Institute Maastricht; PO Box 3973; 6202 NZ Maastricht; The Netherlands.

Received December 30, 2004; accepted April 18, 2005 
Table 1. FP-CIT SPECT: Baseline (=T0), after 3 months methylphenidate (=T1), and after withdrawal methylphenidate $(=\mathrm{T} 2)$ in 5 males with ADHD

\begin{tabular}{|c|c|c|c|c|c|c|c|c|c|c|c|c|c|}
\hline \multirow[b]{3}{*}{ Patient } & \multirow{3}{*}{$\begin{array}{l}\text { Age } \\
(\mathbf{y r})\end{array}$} & \multicolumn{4}{|c|}{ Baseline $^{\mathrm{T0}}$} & \multicolumn{4}{|c|}{3 Months Methylphenidate ${ }^{\text {T1 }}$} & \multicolumn{4}{|c|}{ Follow-Up ${ }^{\mathrm{T2}}$} \\
\hline & & \multicolumn{2}{|c|}{ Left } & \multicolumn{2}{|c|}{ Right } & \multicolumn{2}{|c|}{ Left } & \multicolumn{2}{|c|}{ Right } & \multicolumn{2}{|c|}{ Left } & \multicolumn{2}{|c|}{ Right } \\
\hline & & Caudatus & Putamen & Caudatus & Putamen & Caudatus & Putamen & Caudatus & Putamen & Caudatus & Putamen & Caudatus & Putamen \\
\hline 1 & 8 & 10.47 & 11.22 & 11.96 & 11.07 & 7.55 & 8.67 & 6.95 & 7.97 & 17.12 & 15.51 & 16.72 & 16.31 \\
\hline 2 & 9 & 11.70 & 14.10 & 12.66 & 11.68 & 4.80 & 4.02 & 6.09 & 4.16 & 15.87 & 13.94 & 14.99 & 13.74 \\
\hline 3 & 8 & 11.78 & 11.91 & 11.78 & 12.50 & 5.70 & 7.25 & 5.18 & 6.96 & 12.13 & 13.16 & 11.46 & 14.66 \\
\hline 4 & 9 & 11.50 & 14.10 & 17.00 & 15.80 & 4.14 & 4.02 & 4.34 & 3.84 & 14.65 & 21.37 & 16.22 & 15.94 \\
\hline 5 & 10 & 12.63 & 11.13 & 14.05 & 14.16 & 5.67 & 4.33 & 5.10 & 5.08 & 13.14 & 12.32 & 14.69 & 16.40 \\
\hline
\end{tabular}

Longitudinal FP-CIT SPECT data with: T0 = baseline (drug naïve); T1 = after 3 months of treatment methylphenidate; T2 = 4-6 weeks after

withdrawal of methylphenidate treatment.

Duration of treatment: $9-12$ months in five males with ADHD.

Abbreviations:

ADHD = Attention deficit-hyperactivity disorder

FP-CIT $={ }^{123}$ I-ioflupane

SPECT $=$ Single-photon emission computed tomography

ratios in the basal ganglia compared with normal subjects $[9,10]$. We recently found that imaging of the cerebral dopamine system using single-photon emission computed tomography is a useful instrument to monitor psychostimulant treatment in children with ADHD: a reduction of dopamine transporter activity during methylphenidate treatment was observed [11]. In order to be informed about the potential long-term effects of chronic methylphenidate treatment, in the present study, single-photon emission computed tomography was used to monitor the dopamine system in five males with ADHD after cessation of methylphenidate treatment.

\section{Methods}

\section{Subjects and Procedure}

In the present study, single-photon emission computed tomography was used to monitor the dopamine system in five children with ADHD before $(=\mathrm{T} 0)$, during methylphenidate treatment $(=\mathrm{T} 1)$, and after withdrawal methylphenidate $(=\mathrm{T} 2)$ after a duration of 9-20 months treatment. The study included five children, all right-handed males, mean age 8.54 years; S.D. $=0.88$ years, range $7.3-9.6$ years. Mean intelligence level as measured with the Kaufman Assessment Battery for Children [12] was in the average to low-average range: mean score $88.8 ;$ S.D. = 8.3. Written informed consent was obtained from the parents of all children after the procedures had been explained to the parents and children in detail. The study protocol was approved by an institutional clinical audit. On ethical considerations it was not possible to include in this study the effects of methylphenidate in a matched control sample.

The diagnosis of ADHD included medical, developmental, school, psychosocial data, and family histories obtained by the youth health care practitioner as well as input from parents and teachers, using the Child Behavior Check List and Teachers Report Form, examination by a child neurologist, and neuropsychological assessment to cover the presenting symptoms, differential diagnosis, and possible comorbid conditions [13]. Children included fulfilled the criteria for diagnosis of ADHD, made through a clinical interview, according to criteria set forth in the Diagnostic and Statistical Manual of Mental Disorders, Fourth Edition [14-16].

Apart from the ADHD diagnosis, additional inclusion criteria were: no additional psychiatric disorders, no seizures disorders, no history of tics, normal electrocardiographic and electroencephalographic examination results, and no current or previous psychopharmacologic treatment. The males included manifested inappropriate behavior within the classroom, with severe consequences for their academic and social functioning. On neurologic examination, all children were normal. The child neurologist who examined the subjects also prescribed the methylphenidate medication. The subjects had not received any psychotropic medication whatsoever and were not using any other medication after methylphenidate cessation.

\section{Neuropsychological Instruments}

In addition to single-photon emission computed tomography, medication monitoring was performed by means of neuropsychological testing and assessment of behavioral functioning in the home situation, using the Child Behavior Checklist [17,18] and Teachers Report Form before methylphenidate medication ( $=\mathrm{T} 0$ ), after 3 months of medication ( = $\mathrm{T} 1)$, and after withdrawal of medication $(=\mathrm{T} 2)$. Furthermore, a comprehensive neuropsychological examination was performed at $\mathrm{T} 0$, $\mathrm{T} 1$ and $\mathrm{T} 2$. To test information processing in the children, the Kaufman Assessment Battery for Children [12] was used. This battery is designed for testing children aged 2.5 to 12.5 years, and includes eight subtests (mean score $=10 ;$ S.D. $=3$ ). Based on these eight subscales, two total scales for information processing can be derived: the Sequential information processing scale and the Simultaneous information processing scale (mean score $=100 ;$ S.D. $=15$ ) $[12,19]$. Sequential processing refers to solving problems in which the emphasis is on the serial or temporal order of the stimuli [12] and to measuring the child's ability to tackle and solve problems in turn and with logical consistency. Simultaneous processing is defined as "using a gestalt-like or holistic approach to integrate many stimuli to solve problems" [12,19]. A Continuous Performance Task was used to measure sustained visual attention (Bourdon-Vos test for children [20]). Standard scores can be calculated measuring speed of working and accuracy of working (mean score $=0$; S.D. = 1). The Developmental Test of Visual-Motor Integration (VMI Beery) [21] was used to measure the visuomotor integration abilities. The child must copy geometric forms that become progressively more difficult and which are presented simultaneously with three forms on one page $($ mean score $=100 ;$ S.D. $=15)$.

\section{Procedure}

Neuropsychological medication monitoring was performed by using a Continuous Performance Task (speed and accuracy of working), the Developmental Test of Visual-Motor Integration (VMI Beery), and two subtests of the Kaufman Assessment Battery for Children (auditory working memory and Gestalt closure) [12]. To assess short-term auditory working memory, the Number Recall subtest of the Kaufman Assessment Battery for Children was used. During methylphenidate treatment (T1 = after 3 months of methylphenidate medication), and following with- 
drawal methylphenidate $(=\mathrm{T} 2)$ after a duration of $9-20$ months treatment neuropsychological testing was repeated.

With ${ }^{123}$ I-ioflupane (FP-CIT; Nycomed, Amersham, U.K.) singlephoton emission computed tomography, baseline dopamine transporter integrity in the brain was measured. Single-photon emission computed tomography was performed with a triple head camera (MultiSPECT3, Siemens) equipped with fan-beam collimators. A semi-automatic template model program was used to calculate the ratios between left striatal and right striatal and occipital regions, respectively. Total time of acquisition was 30 minutes ( 45 seconds per frame for 40 views per detector). Zoom factor used was 1.23 , and the matrix size was $128 \times 128$. Filtered back-projection acquisition was performed. Images were filtered using a Butterworth filter with a cutoff value of 0.4-0.5 and an order of 5. A division between the caudate nucleus and putamen was made. The ratios were corrected using Alderson's brain phantom, with known activities in the caudate nucleus and putamen. Scans were not reviewed in a blinded fashion, because we believed that the use of regions of interest led to an acceptable interrater reliability [22].

After baseline single-photon emission computed tomography studies $(=\mathrm{T} 0$ ), the males received methylphenidate at $0.25-0.6 \mathrm{mg} / \mathrm{kg} / \mathrm{day}$. After 3-4 months, single-photon emission computed tomography studies $(=\mathrm{T} 1)$ were repeated, and a child neurologist and a neuropsychologist saw all children again. The neuropsychologist reevaluated the subjects with the instruments mentioned above. It is our policy to withdraw medication during summer holidays. After a drug-free period of at least 4 weeks (mean 5.6; S.D. $=0.54$ ), a third FP-CIT single-photon emission computed tomography $(=\mathrm{T} 2)$ was performed. Scans at $\mathrm{T} 0, \mathrm{~T} 1$, and $\mathrm{T} 2$ were taken under the same conditions. Furthermore, the subjects were again reevaluated by the neuropsychologist.

Data were analyzed with SPSS version 12.0 (SPSS Inc., Chicago, IL). A General Linear Model [23] repeated measures design was used to perform analysis of variance of the FP-CIT single-photon emission computed tomography uptake values before ( $=\mathrm{T} 0$ ), during methylpheniclate treatment $(=\mathrm{T} 1)$, and after withdrawal methylphenidate ( $=\mathrm{T} 2$ ). To compare the results of two subsequent moments, a paired $t$ test was employed.

Table 2. Longitudinal FP-CIT SPECT data: analysis of variance

\begin{tabular}{|c|c|c|c|c|c|}
\hline & $\begin{array}{l}\text { TYPE } \\
\text { III } \\
\text { Sum of } \\
\text { Squares }\end{array}$ & $\mathbf{D F}$ & $\begin{array}{l}\text { Mean } \\
\text { Square }\end{array}$ & $\mathbf{F}$ & Significance \\
\hline Left caudate & 210.845 & 2 & 105.423 & 44.521 & 0.000 \\
\hline $\begin{array}{l}\text { Error } \\
\quad \text { (left caudate) }\end{array}$ & 18.934 & 8 & 2.368 & & \\
\hline Left putamen & 244.273 & 2 & 122.136 & 17.863 & 0.001 \\
\hline $\begin{array}{l}\text { Error } \\
\quad \text { (left putamen) }\end{array}$ & 54.699 & 8 & 6.837 & & \\
\hline Right caudate & 252.134 & 2 & 126.067 & 41.900 & 0.000 \\
\hline $\begin{array}{l}\text { Error } \\
\quad \text { (right caudate) }\end{array}$ & 24.070 & 8 & 3.009 & & \\
\hline Right putamen & 261.930 & 2 & 130.965 & 42.981 & 0.000 \\
\hline $\begin{array}{l}\text { Error } \\
\text { (right } \\
\text { putamen) }\end{array}$ & 24.376 & 8 & 3.047 & & \\
\hline \multicolumn{6}{|c|}{$\begin{array}{l}\text { General linear model; repeated measures at } \mathrm{T} 0, \mathrm{~T} 1 \text {, and } \mathrm{T} 2 \text { : tests of } \\
\text { within-subjects effects. }\end{array}$} \\
\hline \multicolumn{6}{|c|}{ Abbreviations: } \\
\hline \multicolumn{6}{|c|}{$\mathrm{DF} \quad=$ Degrees of freedom } \\
\hline \multicolumn{6}{|c|}{ FP-CIT $={ }^{123}$ I-ioflupane } \\
\hline SPECT $=$ Single & hoton emis & $\operatorname{sion} 0$ & mputed $t$ & nography & \\
\hline
\end{tabular}

Table 3. Paired samples $t$-test: differences in FP-CIT SPECT uptake values in left and right caudate nucleus, respectively, left and right putamen before $(=\mathrm{T} 0)$, during methylphenidate treatment $(=\mathrm{T} 1)$, and after withdrawal of methylphenidate $(=\mathrm{T} 2)$

\begin{tabular}{lcrcc}
\hline \hline & & & & \\
& Pair & T & DF & $\begin{array}{c}\boldsymbol{P} \\
\text { Value }\end{array}$ \\
Left caudate & & & & \\
& T0-T1 & 7.478 & 4 & 0.002 \\
& T1-T2 & -10.126 & 4 & 0.001 \\
Left putamen & T0-T2 & -2.510 & 4 & 0.066 \\
& T0-T1 & 4.599 & 4 & 0.010 \\
Right caudate & T1-T2 & -4.686 & 4 & 0.009 \\
& T0-T2 & -2.065 & 4 & 0.108 \\
& T0-T1 & 5.969 & 4 & 0.004 \\
Right putamen & T1-T2 & -10.303 & 4 & 0.001 \\
& T0-T2 & -1.312 & 4 & 0.260 \\
& T0-T1 & 4.929 & 4 & 0.008 \\
& T1-T2 & -11.644 & 4 & $<0.0005$ \\
& T0-T2 & -2.897 & 4 & 0.044
\end{tabular}

Abbreviations as in Table 2.

\section{Results}

Baseline FP-CIT single-photon emission computed tomography uptake values in the five subjects varied from 11.78 to 17.00 in the right caudate nucleus and from 10.47 to 12.63 in the left caudate nucleus (normal range: $8.23 \pm$ 2.36 ) and were $11.07-15.80$ in the right putamen and 11.13-14.10 in the left putamen (normal range: $9.18 \pm$ 3.71) (Table 1). Follow-up FP-CIT single-photon emission computed tomography in the five males after using methylphenidate for 3 months revealed a reduction of dopamine transporter activity in the right and left caudate nucleus within a range of $42-74 \%$ and $28-64 \%$, respectively. Dopamine transporter activity in the right and left putamen decreased in a range of $28-76 \%$ and $23-71 \%$, respectively. The five males manifested a positive clinical response evaluated by neuropsychological questionnaires and tests during methylphenidate treatment. The period in which medication was used before the third drug-naïve FP-CIT single-photon emission computed tomography was carried out varied from 9 to 20 months.

Dopamine transporter activity in the right and left caudate nucleus varied within a range of 11.46-16.72 and 12.13-17.12, respectively. Dopamine transporter activity in the right and left putamen varied within a range of 14.66-16.40 and 12.32-21.37, respectively. Seventeen of these 20 calculated ratios for dopamine transporter activity were above pretreatment values. The increase of dopamine transporter activity above pretreatment values varied within a range of $3-64 \%$ (mean: $17 \%$ ) (Table 2).

Analysis of variance, using General Linear Modelrepeated measures, documented significant effects: left caudate nucleus $\left(\mathrm{F}_{(2,8)}=44.521, P<0.0005\right)$; right caudate nucleus $\left(\mathrm{F}_{(2,8)}=17.863, P=0.001\right)$; left putamen $\left(\mathrm{F}_{(2,8)}=41.900, P<0.0005\right)$, and right putamen $\left(\mathrm{F}_{(2,8)}=\right.$ 42.981, $P<0.0005)$.

Paired samples $t$ test yielded significant differences of the FP-CIT single-photon emission computed tomography 


\begin{tabular}{|c|c|c|c|c|c|}
\hline & T0 & T1 & $\mathbf{T} 2$ & Chi-Square & Significance \\
\hline CPT speed of working & $-1.00(0.71)$ & $0.75(1.25)$ & $0.60(1.14)$ & 6.50 & 0.039 \\
\hline CPT accuracy of working & $-0.20(1.10)$ & $0.25(0.96)$ & $0.00(0.71)$ & 0.13 & 0.936 \\
\hline Auditory working memory & $-0.86(0.38)$ & $-0.18(0.81)$ & $-0.66(0.46)$ & 1.50 & 0.472 \\
\hline Gestalt closure & $0.06(0.51)$ & $1.10(0.62)$ & $0.86(1.12)$ & 6.16 & 0.037 \\
\hline Visuomotor integration & $-0.60(0.87)$ & $-0.53(0.78)$ & $-1.22(0.44)$ & 1.50 & 0.472 \\
\hline \multicolumn{6}{|c|}{$\begin{array}{l}\text { Differences between mean scores before medication (T0), after } 3 \text { months of medication (T1) and after withdrawal of medication (T2) were analyzed } \\
\text { using Friedman nonparametric test }(\mathrm{n}=5 \text { ). }\end{array}$} \\
\hline \multicolumn{6}{|c|}{ Abbreviation: $\quad$ s } \\
\hline \multicolumn{6}{|c|}{$\mathrm{CPT}=$ Continuous Performance Task } \\
\hline
\end{tabular}

uptake values in left and right caudate nucleus, respectively, left and right putamen before $(=\mathrm{T} 0)$, during methylphenidate treatment ( $=\mathrm{T} 1$ ), and after withdrawal methylphenidate ( $=\mathrm{T} 2$ ) (Table 3). Neuropsychological questionnaires and test results were comparable with pretreatment data (Table 4).

Wilcoxon signed rank test was used to test the significance of the effect between $\mathrm{T} 0$ and $\mathrm{T} 1$ on the one hand and the difference between $\mathrm{T} 1$ and $\mathrm{T} 2$ on the other. As the group of children was small $(\mathrm{n}=5$ ), differences were not significant. We saw a clear tendency of better scores in T1 compared with $\mathrm{T} 0$ especially for speed of working and Gestalt closure, which could be expected as medication was initiated. When comparing T2 with $\mathrm{T} 1$, we saw a tendency to diminished scores, especially in Gestalt closure and visuomotor integration, which is again in accordance with our expectations.

\section{Discussion}

To study possible long-term alterations in the cerebral dopamine system by methylphenidate, single-photon emission computed tomography imaging was used in five males with ADHD after cessation of treatment with methylphenidate. Methylphenidate reduced dopamine transporter activity in the caudate nucleus and putamen in males with ADHD, and after withdrawal of methylphenidate medication an increase of dopamine transporter activity was observed in 17 of the 20 calculated ratios compared with baseline values. Although these data seem to point in one direction, one should be cautious to draw firm conclusions from this, as the numbers are small. We would nevertheless like to make a few points.

Whether this is a simple rebound phenomenon or an active upregulation after treatment with methylphenidate is unclear. To study this phenomenon precisely, more sequential single-photon emission computed tomography scans during treatment would have to be performed. In our small pilot study, we chose a drug-free period of at least 4 weeks, because animal studies demonstrate that, despite the relatively short half-life of methylphenidate, pharmacologic effects on dopamine systems can persist for several days [8].
Little is known of possible consequences of long-term exposure to methylphenidate [24-28]. One study in rats concluded that there is no abuse liability associated with therapeutic methylphenidate treatment [29]. These authors found no increase in dopamine levels in the nucleus accumbens and no sensitized locomotor responses in adolescent rats treated with methylphenidate. Our data after withdrawal of methylphenidate might accord with their observation that methylphenidate does not lead to definite damage of the nigrostriatal dopaminergic pathways [29,30]. However, our data, albeit from a small group of patients, do indicate an increased dopamine transporter activity after cessation of methylphenidate. If one assumes that increased dopamine transporter activity is associated with clinical severity of ADHD, then our observation should be followed up on, to assess whether this rebound phenomenon is temporary or more permanent. It is generally assumed that outgrowth of the disorder ADHD is associated with a decrease per decade of life in striatal dopamine transporters [31].

Taken together, the data presented here seem to support the hypothesis that the dopamine transporter is a primary target for methylphenidate in ADHD [10,31-33]; this seems in contrast with the observation that dopamine transporter gene knockout mice do respond clinically to methylphenidate [34], but others have pointed out that this model does not necessarily represent human ADHD [35]. Although labeled dihydrotetrabenazine appears to be a superior marker for dopaminergic hyperinnervation [36], we believe that the ease of use of single-photon emission computed tomography to assess dopamine transporter activity makes it a superior tool in the clinical setting $[32,33,37,38]$.

\section{References}

[1] National Institute of Mental Health Multimodal Treatment Study of ADHD follow-up: Changes in effectiveness and growth after the end of treatment. Pediatrics 2004;113:762-9.

[2] Conners CK. Forty years of methylphenidate treatment in Attention-Deficit/Hyperactivity Disorder. J Atten Disord 2002;6(Suppl. 1):S17-30.

[3] Jensen $P$. Longer term effects of stimulant treatments for Attention-Deficit/Hyperactivity Disorder. J Atten Disord 2002;6(Suppl. 1):S45-56 
[4] Volkow ND, Fowler JS, Wang G, Ding Y, Gatley SJ. Mechanism of action of methylphenidate: Insights from PET imaging studies. J Atten Disord 2002;6(Suppl. 1):S31-43.

[5] Moderators and mediators of treatment response for children with attention-deficit/hyperactivity disorder: The Multimodal Treatment Study of children with Attention-deficit/hyperactivity disorder. Arch Gen Psychiatry 1999;56:1088-96.

[6] Seeman P, Madras BK. Anti-hyperactivity medication: Methylphenidate and amphetamine. Mol Psychiatry 1998;3:386-96.

[7] Biederman J, Spencer T. Methylphenidate in treatment of adults with Attention-Deficit/Hyperactivity Disorder. J Atten Disord 2002; 6(Suppl. 1):S101-7.

[8] Yuan J, McCann U, Ricaurte G. Methylphenidate and brain dopamine neurotoxicity. Brain Res 1997;767:172-5.

[9] Dresel S, Krause J, Krause KH, et al. Attention deficit hyperactivity disorder: Binding of $[99 \mathrm{mTc}]$ TRODAT- 1 to the dopamine transporter before and after methylphenidate treatment. Eur J Nucl Med 2000;27:1518-24.

[10] Cheon KA, Ryu YH, Kim YK, Namkoong K, Kim CH, Lee JD. Dopamine transporter density in the basal ganglia assessed with [123I]IPT SPET in children with attention deficit hyperactivity disorder. Eur J Nucl Med Mol Imaging 2003;30:306-11.

[11] Vles JS, Feron FJ, Hendriksen JG, Jolles J, van Kroonenburgh MJ, Weber WE. Methylphenidate down-regulates the dopamine receptor and transporter system in children with attention deficit hyperkinetic disorcler (ADHD). Neuropediatrics 2003;34:77-80.

[12] Kaufman AS, Kaufman NL. Kaufman Assessment Battery for Children. Interpretive manual. Circle Pines, Minnesota: American Guide Service, 1983.

[13] Hendriksen JGM, Feron FJM, Njiokiktjien C, Vles JSH. Het effect van clonidine en methylfenidaat bij kinderen met een aandachtstekortstoornis hyperactiviteit. Tijdschr Kindergeneeskunde 2000;98:9499.

[14] Clinical practice guideline: Diagnosis and evaluation of the child with attention-deficit/hyperactivity disorder. American Academy of Pediatrics. Pediatrics 2000;105:1158-70.

[15] Diagnostic and statistical manual of mental disorders, 4th ed. (DSM-IV). Washington, DC: American Psychiatric Association, 1994.

[16] Goldman LS, Genel M, Bezman RJ, Slanetz PJ. Diagnosis and treatment of attention-deficit/hyperactivity disorder in children and adolescents. Council on Scientific Affairs, American Medical Association. JAMA 1998;279:1100-7.

[17] Achenbach TM. Manual for Child Behavior Checklist/4-18 and 1991 Profile. Burlington: University of Vermont Department of Psychiatry, 1991.

[18] Verhulst FC, Koot JM, van der Ende J. Handleiding voor de CBCL (Child Behaviour Checklist). Rotterdam, Netherlands: Afd. Kinder- en Jeugdpsychiatrie, Erasmus University Medical Centre, 1996.

[19] Hurks PPM, Hendriksen JGM, Feron FJM, Jolles J, Vles JSH. Information processing in ADHD children with or without learning disabilities. In: Neuropsych Publishers. The influence of environment, behaviour, and attention deficits on cognitive development in schoolaged children. Maastricht: Maastricht University, 2003:143-62.

[20] Vos PG. Bourdon-Vos test: Handleiding (3de herziene uitgave)-Manual for the Bourdon-Vos test. Lisse, Netherlands: Swets en Zeitlinger, 1998.
[21] Beery KE. The Beery-Buktenica Developmental Test of VisualMotor Integration (VMI). Parsippany, NJ: Modern Curriculum Press, 1997.

[22] Lobaugh NJ, Caldwel] CB, Black SE, Leibovitch FS, Swartz $\mathrm{RH}$. Three brain SPECT region-of-interest templates in elderly people: Normative values, hemispheric asymmetries, and a comparison of singleand multihead cameras. J Nucl Med 2000;41:45-56.

[23] Ferron J. Reconsidering the use of the general linear model with single-case data. Behav Res Methods Instrum Comput 2002;34:32431 .

[24] Gadow KD, Sverd J, Sprafkin J, Nolan EE, Grossman S Long-term methylphenidate therapy in children with comorbid attentiondeficit hyperactivity disorder and chronic multiple tic disorder. Arch Gen Psychiatry 1999;56:330-6.

[25] Stiebel V, Kemp K. Long-term methylphenidate use in the medically ill patient with organic mood syndrome. Psychosomatics 1990;31:454-6.

[26] Volkow ND, Insel TR. What are the long-term effects of methylphenidate treatment? Biol Psychiatry 2003;54:1307-9.

[27] Weiss G, Kruger E, Danielson U, Elman M. Long-term methylphenidate treatment of hyperkinetic children. Psychopharmacol Bull 1974; 10:34-5.

[28] Weiss G, Kruger E, Danielson U, Elman M. Effect of long-term treatment of hyperactive children with methylphenidate. Can Med Assoc J 1975;112:159-65.

[29] Kuczenski R, Segal DS. Exposure of adolescent rats to oral methylphenidate: Preferential effects on extracellular norepinephrine and absence of sensitization and cross-sensitization to methamphetamine. J Neurosci 2002;22:7264-71.

[30] Greenhill L, Beyer DH, Finkleson J, et al. Guidelines and algorithms for the use of methylphenidate in children with AttentionDeficit/Hyperactivity Disorder. J Atten Disord 2002;6(Suppl. 1):S89100 .

[31] Volkow ND, Ding YS, Fowler JS, Wang GJ, Logan J, Gatley SJ, et al. Dopamine transporters decrease with age. J Nucl Med 1996;37:554-9.

[32] Dougherty DD, Bonab AA, Spencer TJ, Rauch SL, Madras BK, Fischman AJ. Dopamine transporter density in patients with attention deficit hyperactivity disorder. Lancet 1999;354(9196):2132-3.

[33] Krause KH, Dresel SH, Krause J, Kung HF, Tatsch K. Increased striatal dopamine transporter in adult patients with attention deficit hyperactivity disorder: Effects of methylphenidate as measured by single photon emission computed tomography. Neurosci Lett 2000;285: 107-10.

[34] Gainetdinov RR, Wetsel WC, Jones SR, Levin ED, Jaber M, Caron MG. Role of serotonin in the paradoxical calming effect of psychostimulants on hyperactivity. Science 1999;283(5400):397-401.

[35] Sarkis EH. "Model" behavior. Science 2000;287(5461):2160-2.

[36] Meyer P, Bohnen NI, Minoshima S, et al. Striatal presynaptic monoaminergic vesicles are not increased in Tourette's syndrome. Neurology 1999;53:371-4.

[37] Amen DG, Carmichael BD. High-resolution brain SPECT imaging in ADHD. Ann Clin Psychiatry 1997;9:81-6.

[38] O'Tuama LA, Treves ST. Brain single-photon emission computed tomography for behavior disorders in children. Semin Nucl Med 1993;23:255-64. 